forms in rivers, and is the term applied to ice formed on and attached to the bottom of rivers. This anchorice is only formed in rivers where the current is too swift for surface-ice to form, and not in depths exceeding 40 feet to 45 feet, though in the clear seawater off the coast of Newfoundland it is largely formed at depths of 60 feet to 70 feet. Its formation appears to be rightly attributed to loss of heat in the bed of the river from radiation, for it occurs on clear, cold nights, and is impeded by any form of shelter interfering with radiation, such as under a bridge; it does not form at all under surface-ice arresting radiation, and is less below a turbulent river than in a clear, still sea. Frazil-ice is the cause of the packing up of the ice and of the floods of the St. Lawrence, and also of the obstruction to the working of the power plants in the winter. When a river is completely frozen over, the channel is protected from the formation of frazil-ice or anchor-ice, unless there is an expanse of open water above, from which frazilice, and in mild weather anchor-ice, is carried down. To prevent the stoppage of the power works in the latter case, the author suggests that the gates, the rack for arresting débris, and the wheels should be placed under shelter; that the iron bars of the rack should be heated; and that the passage of the frazilice should be facilitated as much as possible, and prevented from agglomerating by the occasional injection of steam.

\section{ROMANTIC INDIA.}

Under the Sun: Impressions of Indian Cities. By P. Landon. Pp. xii +288 ; illustrated. (London: Hurst and Blackett, Ltd., I906.) Price I2s. $6 d$. net.

THIS is one of the crop of books on India by Press correspondents who visited the great Eastern dependency during the recent tour of the Prince of Wales. Its author had previously on one or two occasions spent some weeks in the country, and now presents part of his already published letters "recast in a more permanent form." It is perhaps inevitable that the great bulk of the impressionist literature on the East should issue from the hurried pens of the cold-weather globe-trotters, whose "butterfly zigzags" over the country undoubtedly enable them often to see things from fresh and comparative, if somewhat superficial, standpoints. With all India to roam over, it would be surprising did the oft-told tale of Indian cities not bear some repetition at the hands of such an imaginative journalist as Mr. Landon. He certainly has produced a readable book, though many of his sketches convey less clear-cut impressions of the places than those of some other writers who have gone over the ground before, Steevens, for instance; and they lack proportion. Some point is seized on and overstrained with a discursiveness that causes the reader at times to lose the thread of the narrative, whilst other more characteristic features of the picture are omitted.

The author betrays a weakness for unnecessarily dragging in vernacular names (some of which are misspelt, e.g. "bebel," which occurs a dozen times NO. 1942, VOL. 75] for "bābul," the Acacia arabica), with no word of explanation to the reader as to what the thing is, and his too frequent use of superlatives leads him into meeting the most transcendental thing "on earth" many times on his trip. Thus we are told within a hundred pages that at Udaipur "one room is without rival on earth." The Indian antelope and cheetah are "two of the fastest animals on earththe cheetah is beyond all question the swiftest." Jaipur has " colours that only Mandalay of all places in the world can hope to rival." A "dishonest and fugitive jeweller from France" is " the first decorator of all known periods." The Delhi grand trunk-road is "the most historic highway in the East." Although the Taj is "the crown and goal of all that India has of beauty and romance," the Queen's monastery at Mandalay is "the most picturesque place in the East, probably in the world," though a few pages previously we read that the Shwe Dagon pagoda at Rangoon also is "the most picturesque place in all the East."

As to details, he is not over careful; he speaks of bread-fruit "palms," and of the reedy banks of Calcutta "flaming with patches of rose lotus"-this might be the case if lotuses grew on banks, but they do not. At Darjiling, he says, "the valley stretches out ten miles wide from the foot of the precipice "; as a fact, the valleys there are narrow ravines, none of which has a width of more than a quarter of a mile at its bottom. The photographs of the hackneyed views one has so often seen before are good and well reproduced; the same, however, cannot be said for the coloured prints, which are unpleasantly low-toned from a too liberal application of dull paint; the sombre view of "the sunset glories of the Hugli" is utterly unlike what it is meant to represent.

A chapter is added on the later life of the notorious rebel and fugitive of Mutiny days, Nana Sahib, purporting to give " historical facts here presented for the first time." No one, however, can seriously be expected to accept as evidence the old re-discovered bazaar rumours picked up by a passing traveller and set down without absolutely any proof whatever in support of them, all the more so as such an experienced Anglo-Indian magistrate as Sir Dennis Fitzpatrick, commanding the resources of the Imperial secret police, was specially deputed to sift such rumours at the time, and finally rejected them as wholly unfounded. There is no index, but this, perhaps, is unnecessary for fugitive sketches.

\section{OUR BOOK SHELF.}

Species and Varieties: Their Origin by Mutation. Lectures delivered at the University of California. Second Edition, Corrected and Revised. By H. De Vries; edited by D. T. MacDougal. Pp. xviii + 847. (Chicago: Open Court Publishing Co. ; London: Kegan Paul and Co., Ltd., I9o6.)

IT is not surprising that the first edition of De Vries's lectures in America should be followed by a second after the lapse of a year. All the misprints that we pointed out in our review of the first edition have been corrected; and even our suggestion that uniformity in the termination of the adjectives derived from such terms as physiology was 